\title{
Students' perceptions on Internship Program: Effectiveness and Problems
}

\author{
Erwin Gay ${ }^{1}$, Faujia Umasugi ${ }^{2}$, Maryanti Rasid ${ }^{3}$ \\ \{erwin_gay@yahoo.com ${ }^{1}$ \} \\ English Education Department, University Muhammadiyah Maluku Utara, 97719, Indonesia ${ }^{1,2,3}$
}

\begin{abstract}
This study aims to explore the students' perceptions about internship program Held by Faculty of Education (FIP), Muhammadiyah University of North Maluku (UMMU). The study employs a mixed method of quantitative and qualitative approach. The research subjects were 40 students of English Education Department and Primary School Teacher Department (PGSD), FIP-UMMU. Data was collected through five-point likert scale and in-depth interviews. Findings showed that most students achieve the experiences and benefits during the internship program such as reflecting critically on teaching methodology in actual setting, developing a school curriculum, and adjusting to school environment, school teachers, and the local community. It also gives them the opportunity to integrate theory with practice, design teaching aids and material then implement the lesson properly, and improve the classroom management. Problems faced by students during the internship are several junior and high school students have bad attitudes that make student-teachers are difficult to manage the class. Very few studentsteachers also have less preparation before class, therefore they cannot deliver the lessons in a proper way. Therefore, the committee of the program should work out a mechanism of obtaining feedback from school's instructor and college supervisor about students' attitude which should form part of the students' appraisal process.
\end{abstract}

Keywords: Students; Perception; Internship

\section{Introduction}

Nowadays, the world of education needs creative, qualified and professional teacher candidates. To achieve this goal, prospective teachers are required to have knowledge and skills in teaching by accomplishing their study at the university in Teaching Preparation Program in joining teaching practice at school.

Steffy, Wolfe, Pasch, and Enz [1] assert that undergraduate education for aspiring teachers can be perceived "as one end of a continuum that spans the entire career of a teacher". The preparation teachers receive while in college begins their professional journeys and determines what standard of excellence they will pursue throughout their careers.

During the internship program, student-teachers have a standard level of competence as required by the real work environment, Daryanto [2] because they will always be observed, cared for, heard, and imitated and even assessed by instructors and supervisors regarding their appearance in class, personality, ability to master learning material, teaching skills, attention to students, the relationship between students and teacher, attitudes, and behavior both in class and in school environment. 
The researchers are two of students' field supervisors and one of the university students who has experienced in internship programs in two months at SMP Negeri 1 Makian held by Faculty of Education (FIP), Muhammadiyah University of North Maluku (UMMU). Based on the observation during the program on July to September 2019, it can be stated that the internship program is quite successful in providing experience and benefits for students, even though there are few problems faced by participants during the program.

Otara [3] expressed that the advantages that students acquire from this internship program is that it actually obtains training as professional teacher candidates by directly practicing teaching in the settings, but also as professionals learning their own teaching practice, taking part in site-based decision making, and coordinating their work with teachers and other members of the school community. This practice guides the students to develop the confidence to work with learners in real situations during their school practice stated by Kagoda \& Sentong [4]. The experiences also gained by students that allow them to be immersed in the classroom setting and become better acquainted with all aspects of a school and of teaching. Thus, internship program that utilize by each institution [including FIP-UMMU] requires students to have the school experiences more effectively and prepare future teachers than do traditional campus-based programs as was confirmed by Steffy, et. Al [1].

In contrast, the most problems face by researcher and other participants are coming from students themselves such as managing the class and mastering the materials. Another one is coming from the school environment that there are not sufficient interesting teaching media. Therefore, the school instructor should control and advice to the participant regularly during their practice in class or out class. In addition, the school instructor and college supervisor require to change students' perception and have positive view of the practice. It is then they would be able to achieve more knowledge from the programme and eventually perform optimally in their pedagogical skills on the actual setting, Olugbena [5].

Thus, the study seeks to achieve aforementioned purposes and the issues to be discussed in this paper will be summarized in the following research questions: what are the students perceptions on internship program held by the committee in Faculty of Education, Universitas Muhammadiyah Maluku Utara”. It hopes that the better findings can solve the problems for the future internship program.

\section{Method}

This is a qualitative study backed up by simple quantitative statistics focusing on the perception of 20 English Education Department students and 20 Primary School Teacher Departments (PGSD), FIP-UMMU toward their internship experiences. They were selected using stratified that was used to select sample according to students' level, programme and gender. The study adopted the concurrent triangulation design which allowed the researcher to collect both quantitative and qualitative data concurrently and to compare the data to figure out if there is convergence, differences, or some combination as argued by Creswell [6].

Data was collected from 40 active students above the seventh semester who have been taking three internship program courses, namely Magang I, Magang II, and Magang III at junior and high schools in Ternate and Pulau Makian through five-point likert scale and in-depth interviews. These both tools were properly tested in order to confirm their validity and reliability. The data collected through questionnaire consists of 10 closed-ended questions was analyzed by using descriptive statistical procedure of percentages. Meanwhile, the interview 
consist of 5 questions was analyzed qualitatively. All recorded information from interviews was counted, reviewed several times, and coded to formulate outcomes and themes.

\section{Results and Discussion}

\subsection{Result}

There are very diverse perceptions of students, but researchers summarize the perceptions of these students into two categories base on the research question, namely: positive and negative attitudes during internship program.

\subsubsection{Positive Attitudes during the Internship Program}

Basically, there is no student complain about the three times internship program (Magang I, II, and III) held by FIP-UMMU. However, there are some positive statements conveyed by respondents based on their opinions, which are the increase of teaching skill in actual setting, the improvement of developing a school curriculum, and the adjustment to school environment, school teachers, and the local community.

Respondent 1 said that internships can improve the ability of each student to organize classes. "Internship program at junior and high schools held by FIP-UMMU can improve the ability of every student who participates in the internship such as manage the class or face the students that come from various cultural background." He also added that by joining the internship program students got many benefits. "After joining the internship program, my opinion is "Alhamdulillah", I got a lot of benefits such as designed and implemented lesson in a real classroom and developed the teaching materials.

Meanwhile respondent 2 said that participating the internship program can examine students' mentality in real situation. "This internship program is beneficial for students because students can examine their mental skills in delivering the lessons".

Respondent 2 also added that the internship program is a useful activity because students can teach by adjusting the classroom and school atmosphere. "This activity is advantageous because the participants can teach by adapting the classroom and school atmosphere, where they have in their mind that this is a real job of teachers. They should deliver the lessons in any kind of situation.

In contrast to respondent respondents 1 and 2, respondent 3 said that the impression during the internship was that he could manage the class and understand and develop the educational curriculum. "The impression of being able to manage the class and being able to understand the curriculum."

She also added that he gained benefits, experience, and teaching practice includes the suggestion of critical thinking from school instructor and university supervisor during the internship. "I Get a lot of benefits, experience and teaching practice during the internship program, such as it gives me opportunity to integrate theory and practice, plan and deliver lessons properly, and critically analyzed my own teaching styles in the light of feedback given by school instructor and university supervisor.

In addition to the impressions of other respondents, respondent 4 said that during the internship program, he was familiar with the classroom atmosphere and the school environment. 
"I Can get to know the classroom atmosphere, the school environment, and delivering material with the high responsibility."

\subsubsection{Negative Attitudes during the Internship Program}

Negative perception means that the obstacles faced by participants during the internship program.

"The obstacles conveyed by students is from the school environments and from students themselves, such as: (1) students are naughty (2) students do not have the preparation before class. Respondent 5 said that the real obstacles were students, students who were wayward. "The real obstacle lies is in the wayward students."

In addition to respondent 5, respondent 6 said that the obstacles in participating in the internship program was not having the preparation before class. "Obstacle during the internship is without preparation before class. Therefore, I do not have any encouragement to stand in front of students to deliver the materials"

\subsubsection{Questionnaire Analysis}

In the questionnaire, 10 statements about internship were divided into two categories, namely 5 positive statements of student perceptions and 5 negative statements of student perceptions. The Respondents' Answer on the Statements show in Table 1.

Table 1. The Respondents' Answer on the Statements

\begin{tabular}{|c|c|c|c|c|c|}
\hline & $\begin{array}{l}\text { Fully } \\
\text { Agree }\end{array}$ & Agree & Neutral & Disagree & $\begin{array}{c}\text { Highly } \\
\text { Disagree }\end{array}$ \\
\hline \multicolumn{6}{|l|}{ Positive Questions } \\
\hline 1.integrate theory with practice & $50 \%$ & $40 \%$ & $5 \%$ & $5 \%$ & $0 \%$ \\
\hline $\begin{array}{l}\text { 2.reflect critically on teaching style and } \\
\text { practice }\end{array}$ & $40 \%$ & $25 \%$ & $25 \%$ & $0 \%$ & $10 \%$ \\
\hline $\begin{array}{l}\text { 3.refine and improve teaching } \\
\text { methodology and techniques }\end{array}$ & $50 \%$ & $40 \%$ & $10 \%$ & $0 \%$ & $0 \%$ \\
\hline 4.design and implement the lessons & $65 \%$ & $20 \%$ & $15 \%$ & $0 \%$ & $0 \%$ \\
\hline 5.design teaching aids and material & $45 \%$ & $40 \%$ & $10 \%$ & $5 \%$ & $0 \%$ \\
\hline \multicolumn{6}{|l|}{ Negative Questions } \\
\hline $\begin{array}{l}\text { 1.not gain any experience while joining } \\
\text { the internship program }\end{array}$ & $10 \%$ & $0 \%$ & $20 \%$ & $25 \%$ & $45 \%$ \\
\hline $\begin{array}{l}\text { 2.not achieve any benefits during the } \\
\text { internship program }\end{array}$ & $10 \%$ & $15 \%$ & $0 \%$ & $20 \%$ & $55 \%$ \\
\hline $\begin{array}{l}\text { 3.not add insight and knowledge, } \\
\text { especially about the educational } \\
\text { curriculum }\end{array}$ & $5 \%$ & $0 \%$ & $20 \%$ & $25 \%$ & $50 \%$ \\
\hline $\begin{array}{l}\text { 4.not improve skills in class } \\
\text { management }\end{array}$ & $5 \%$ & $5 \%$ & $25 \%$ & $20 \%$ & $45 \%$ \\
\hline $\begin{array}{l}\text { 5. not like the internship regulation } \\
\text { stated by the internship committee }\end{array}$ & $10 \%$ & $5 \%$ & $5 \%$ & $15 \%$ & $65 \%$ \\
\hline
\end{tabular}

Table 1 shows that most English Education Department students $(\mathrm{SA}=50 \%$, Agree $=40 \%)$ in the study agreed that internship program integrate theory with practice. Teacher-students (SA $=40 \%$, Agree $=25 \%$ ) also believed that this program was effective and beneficial because it 
provided an opportunity for them to plan, deliver lessons, and gave opportunity to reflect critically the different teaching styles and practice, but $10 \%$ disagreed with this statement. However, participants $(\mathrm{SA}=50 \%$, Agree $=40 \%$ ) reported that through this program their teaching styles, methodologies and techniques were refined and improved. Moreover, students $(\mathrm{SA}=65 \%$, Agree $=20 \%)$ stated that internship program enhanced their ability in designing and implementing the lessons to junior and high school students. In the last positive statement, the majority of the respondents strongly agree $(45 \%)$ and agreed $(40 \%)$ that by joining the internship program held by FIP-UMMU, it improved their ability to design and use teaching aids and materials in a more effective and better way.

Then, the majority of English Education Department students ( $\mathrm{HD}=45 \%$ and $\mathrm{D}=25 \%)$ in this study disagreed that internship program does not provide any experience while joining the internship program. it means that English department students gain a lot of experiences when they participate in the internship program. $55 \% \mathrm{HD}$ and $20 \% \mathrm{D}$ of teacher-students also opined that they do not achieve any benefits during the internship program. It means internship program gave them experiences in teaching practice and real classroom environment. In addition, a half (HD) and a quarter (D) of participants disagreed that through internship program, they can not add insight and knowledge, especially about the school curriculum, but 5\% agreed with this statement. It means that this internship program can enhance students to learn in adding insight and knowledge of ways to be good teachers. Participants $(\mathrm{HD}=45 \%, \mathrm{D}=20 \%)$ disagreed that they cannot improve skills in classroom management during the program. It means that by joining the internship program held by FP-UMMU, their ability of classroom management was enhanced. The last negative statements, student-teachers $(\mathrm{HD}=65 \%, \mathrm{D}=15 \%)$ disagreed that they do not like the internship regulation stated by the internship committee. It means that English Education department students really enjoy the regulation stated by the internship committee.

\subsection{Discussion}

There are two statements perceived by English department students from this data; (1) Positive attitudes during the internship and (2) negative attitudes during the internship.

\subsubsection{Positive attitudes from data interview and questionnaire}

There are many positive statements were obtained individually by students after participating in the internship program. Namely, the increase of teaching skill in classroom setting, the improvement in developing an educational curriculum, and the adjustment to school environment, school teachers and the local community.

This internship program is a successful way to provide effective practice to the students about real place of work for those who tend to be teachers after graduating from undergraduate degree, Parveen [7]. It provides an opportunity to integrate theory and practice in teaching. Otara [3] found that this training program assists student to organize and deliver lessons in appropriate way, critically analyze their own and peers teaching styles and improvement. Encouraging internship program is therefore critical to improve the strategy of pedagogic, which will promote student learning and in improving the quality of education.

\subsubsection{Negative attitudes from data interview and questionnaire}


Negative statements from student perceptions in the form of obstacles that were obtained when participating in the internship program were; some students who were from various cultural background that have bad character during the lessons. In addition, prospective teachers also have no preparation in implementing the materials. Even though the majority of students have the positive attitudes during the internship, there are 10 per cent of students strongly agree that they cannot gain experience while joining the internship program, they cannot achieve any benefits during the internship program, they do not like the internship regulation stated by the internship committee.

\section{Conclusion}

The findings of the study indicate that student-teachers have a positive and negative perception during the internship program. Most students achieve a lot of experiences and benefits such as reflecting critically on teaching methodology in actual setting, developing a school curriculum, and adjusting to school environment, school teachers, and the local community. In addition, it gives them the opportunity to integrate theory with practice, design teaching aids and material then implement the lesson properly, and improve the classroom management. Through the internship program, student-teachers increase their professional knowledge that they can be an English teacher in the future because it provides the access for student to be effective teachers. In contrast, very few junior and high school students have bad character that make students-teachers are difficult to manage the class. Some students also have less preparation before class; therefore, they cannot deliver the lessons properly. Therefore, the committee of the program should work out a mechanism of obtaining feedback from school's instructor and college supervisor about students' attitude which should form part of the students' appraisal process. For further researchers who are interested in studying the activities of the internship program, it is hoped that they can develop the research that has been done using good research indicators in the implementation of internship program activities in different research or broader research variables.

\section{Acknowledgement}

We acknowledge the committee of 2nd Borobudur International Symposium (BIS) on Humanities and Social Sciences hosted by Universitas Muhammadiyah Magelang, rector of the Muhammadiyah University of North Maluku: Dr Saiful Deni, S.Ag., reviewer and proove reader, and research team. We would also like to express our gratitude to the students of English Education Department who were willing to participate in this venture.

\section{References}

[1] Steffy, B. E., Wolfe, M. P., Pasch, S. H., \& Enz, B.J. Life cycle of the career teacher. Thousand Oaks, CA: Corwin Press. 2000.

[2] Daryanto, Panduan Proses Pembelajaran Kreatif \& Inovatif teori \& Praktek Pengembangan dalam Profesionalisme Bagi Guru, Jakarta: CV. AV Publisher. 2009. 
[3] Otara. Students' Perception on Education Internship Program Inrwanda: Effectiveness and Challenges. European Journal of Educational Scicence. Vol.1 No.2. June 2004

[4] Kagoda \& Sentongo. Practicing Teachers' Perceptions of Teacher Trainees: Implications for Teacher Education. Universal Journal of Educational Research 3(2): 148-153, 2015

[5] Olugbenga, J, A. Perception of Students towards Participation in Teaching Practice Exercise in Ekiti State University, Ado- Ekiti. International Journal of Academic Research in Progressive Education and Development, Vol. 2, No. 4 ISSN: 2226-6348. October 2013

[6] Creswell, J.W. Chapter One, A Framework for Design. Research design: Qualitative, quantitative, and mixed methods approach. Thousand Oaks, CA: Sage Publications. 2003

[7] Parveen. Internship Program in Education: Effectiveness, Problems and Prospects. International Journal of Learning \& Development. International Journal of Learning \& Development. ISSN 21644063 2012, Vol. 2, No. 1 